\title{
Development and Performance Evaluation of a Manually Operated Seed-Cum Fertilizer Soybean Planter
}

\author{
Devesh Kumar* and Ashok Tripathi \\ Department of Farm Machinery and Power Engineering, SHUATS Allahabad, U.P., India \\ *Corresponding author
}

\begin{tabular}{l} 
K e y w or d s \\
$\begin{array}{l}\text { Performance } \\
\text { evaluation, Manually } \\
\text { operated, Fertilizer. }\end{array}$ \\
\hline Article Info \\
$\begin{array}{l}\text { Accepted: } \\
\text { 24 September } 2017 \\
\text { Available Online: } \\
10 \text { November } 2017\end{array}$ \\
\hline
\end{tabular}

A B S T R A C T
Soybean is produced today mainly for its protein and oil components. Commodity soybean seeds consist of approximately $40 \%$ protein and $20 \%$ oil on a dry weight basis (Liu, 1997). One metric ton of soybean yields an average of $183 \mathrm{~kg}$ of oil and $800 \mathrm{~kg}$ of protein meal. Soybean meal contains $44 \%$ or $48 \%$ protein the average Depth of $4.01 \mathrm{~cm}$ seed to seed spacing was $25 \mathrm{~cm}$ respectively. Damaged seed Percentages of soybean during damage test of manually operated seed-cum fertilizer soybean, planter in lab was found to be null. The Pushing angle of handle, pushing force, draft force and drawbar power in different soil sandy loam soil, Clay loam soil was found, $15.21 \mathrm{~kg}$, and $0.0966 \mathrm{hp}$ respectively. Effective field capacity of 0.229 , was obtained for continuous operation of the planter in different forward speed of $2.0 \mathrm{~km} / \mathrm{hr}, 2.5 \mathrm{~km} / / \mathrm{hr}, 3.0 \mathrm{~km} / \mathrm{hr}$, for planting soybean and field efficiency for soybean, was $94.78 \%$, respectively. The manufacturing cost of the developed manually operated seed-cum fertilizer soybean planter was Rs. 4602. The average annual cost of the manually operated planter was Rs.225.5, per hectare for soybean planter. The manually operated seed-cum fertilizer soybean planter can save about 93.47\% planting cost for crops cultivation. Overall performance of the manually operated seed-cum fertilizer soybean was found quite satisfactory.

\section{Introduction}

The soybean (Glycine max) is a legume species native to East Asia, which is highly cultivated for its edible seed. The plant has been classified under oil producing plant for its edible seed rather than for its pulse by the Food and Agricultural Organization (FAO). Soybean is an annual legume categorized under Fabaceae family. Soybean is one of the most important beans among all in the world which provides vegetable protein for millions of human and ingredients for thousands of chemical products. It is most nutritious and easily digested food of the bean family. The soybean is considered as one of the richest and cheapest sources of protein. It is a staple in the diet of humans and animals in different corners of world today. The seed contains 17 percent oil and 63 percent meal, 50 percent of which is protein. Soybean is a good source of protein for diabetics as it contains no starch. Globally, the most important feed grain legume is soybean (Glycine max), with a total production of 216,144,262 tones and harvested area of 94,899,216 hectors (Faostat, 2009). Today, the world's top most producers of soybean are USA, Brazil, Argentina, India and China. Approximately 85 percent of the world's soybeans are processed, or "crushed," 
annually for the production of soybean meal and oil and 98 percent of the soybean meal that is crushed is further processed for preparation of animal feed. About 95 percent is consumed as edible oil; the rest is used for industrial products such as in the production of fatty acids, soaps and biodiesel. Soybean is an agricultural crop of great importance as many important proteins and non-protein aqueous compounds have been isolated. Soybean (Glycine max) seeds are known to contain different proteins which have anti nutritional and/or toxic effects, such as soybean agglutinin (an N-acetyl galactosamine-specific lectin). Cultivation of soybean is done mostly during the Kharif seasion, rainy season. Seeds are sown in rows of about 45 to $60 \mathrm{~cm}$ apart and plants are spaced about $15 \mathrm{~cm}$ apart within rows. Seeds may be soaked for 24 hours to soften the hard seed coat and induce better germination (Dessai et al., 1997). Soybean can be harvested fresh and included in meals. Dried and stored for consumption during offseason periods. Sowing soybean by hand increases production cost as extra man-hours is required for thinning operation as excessive seed is inevitably sown per hill. Moreover, the traditional planting method is tedious, causing fatigue and backache due to the longer hours required for careful hand metering of seeds if crowding or bunching is to be avoided. Soybean is produced today mainly for its protein and oil components. Commodity soybean seeds consist of approximately $40 \%$ protein and $20 \%$ oil on a dry weight basis (Liu, 1997). One metric ton of soybean yields an average of $183 \mathrm{~kg}$ of oil and $800 \mathrm{~kg}$ of protein meal (Snyder, 1987). Soybean meal contains $44 \%$ or $48 \%$ protein depending on the type of processing used to produce the soybean meal (Maier et al., 1998). Most soybean protein, in the form of defatted meal, is used as animal feed for poultry and swine. In 2004, the USDA (2005) reported that $67 \%$ of protein meal consumed in the world was produced from soybean. Food products enhanced by soybean protein for human consumption are also widely used and accepted.

\section{Materials and Methods}

\section{Description of the seed-cum fertilizer soybean planter}

The development seed-cum fertilizer soybean planter consist of the handle, seed hopper, furrow opener, furrow covering device, and drive wheel, seed discharge tube, fertilizer discharge tube, and seed metering houses.

\section{Handle}

The handle consist of the G.I pipe use in the planter Length of the handle is calculated based on average standing height of female operator. So, the average standing height of women workers is the $100 \mathrm{~cm}$. Distance of wheel centre from the operator (for operator height of 95-105 cm) in operating condition is the $115 \mathrm{~cm}$. therefore angle of inclination.

\section{Seed hopper}

The amount of seed contained depends upon the size of the seed hopper. The shape of hopper was designed at the top. The volume of seed hopper was $13129.94 \mathrm{~cm}^{3}$. The height bottoms to top of seed hopper were $305 \mathrm{~mm}$ and $254 \mathrm{~mm}$ square at the top. To obtain free flow of seeds, the slope of the hopper was fixed at $32^{0}$, which is modestly higher than the average angle of repose of the seeds. The material was used for the design $2.5 \mathrm{~mm}$ thick mild steel metal sheet for low cost, light weight and longer life.

\section{Fertilizer hopper}

Similar to the seed box, the fertilizer seed box was also made with 20 gauge M.S sheet 
$305 \mathrm{~mm} \times 257 \mathrm{~mm}$ sheet was taken for the fertilizer box bottom. At the bottom of the fertilizer box and keeping the 127 side vertical with vertical so that the fertilizer box could maintain with slop horizontal at $32^{0}$.

\section{Furrow opener}

The tine of furrow assembly was made of M.S flat of size $40 \times 10 \mathrm{~mm}$. The boot was made of mild steel sheet of $1.6 \mathrm{~mm}$ thickness. High carbon steel was used for making shoe and cutting edge inclined at angle of a $45^{\circ}$. The seed and fertilizer tube were welded to the separator in such a way that fertilizer was dropped 500 ahead and $10 \mathrm{~mm}$ deep to the seed.

\section{Drive wheel}

A small bicycle rim type wheel with diameter $490 \mathrm{~mm}$ was provided to transmit the traction power of wheel to the metering unit through chain-sprocket drive. The wheel was located in the centre at the rear of the planter.

A shaft was provided that keeps the drive wheel always in contact with the ground surface to minimize wheel slippage. The drive wheels are made of steel and are integral parts of the seed metering mechanism. The drive wheel is made of steel. The diameter of the wheels is $38 \mathrm{~cm}$ was coupled to the seed/fertilizer template drive shaft.

\section{Seed tube and fertilizer tube}

The seed tube was made of rubber pipe 32 $\mathrm{mm}$ diameter and $304 \mathrm{~mm}$ long. Two end of the seed and fertilizer tube connected to lower pipe of seed and fertilizer metering house and other end connected furrow opener. Seeds picked from the hoppers pass through the upper hole at the slide of the castellated metering mechanism to the lower hole into the discharge tube which deposits the seeds at desired uniform spacing into the opened furrow.

\section{Furrow covering device}

The furrow covering device is made of rectangular mils steel plate of dimension $70 x$ $115 \mathrm{~mm}$. It was fasted with welded on the main frame. The furrow covering device is perpendicular to the direction of travel of the planter to be facilated proper covering of the soil.

\section{Metering device}

Seed metering wheel type use in planter. The diameter and numbers of cells was determined on the basis of mean size of individual seeds, recommended intra-row spacing of seeds and economical and efficient size (diameter) of driving wheel. Two same metering wheels were used to handle the seeds of soybean crops. Wheel diameter 102 $\mathrm{mm}$. The diameter of the ground wheel was $177 \mathrm{~mm}$.

\section{Design consideration of the seed-cum fertilizer soybean planter}

The following considerations were used for the design of manually operated seed-cum fertilizer soybean planter.

Meter seeds of different sizes and shape for seed and fertilizer.

The safety of the operator

The operation of the machine should be simple for small scale or rural farmers.

The materials available locally were used in the fabrication of the all components.

Cost of the materials for construction was less. 
Easy to operate (both male and female can be operating).

\section{Design of the seed-cum fertilizer soybean planter}

The seed-cum fertilizer soybean planter consist on the vertical wheel type metering device and both devices also fixed in seed mechanism house. The attachment of the furrow opening device which opens the furrow for the seed and fertilizer (Fig. 1).

\section{Laboratory test}

The planter was calibrated in the laboratory to determine the rate of discharge, evenness of seed spacing in rows and seed damage. The soybean seed variety called Pusa -16 popularly grown by local farmer was purchased from Alopi Chungi market in Allahabad U.P. There seed have average Moisture content $12 \%$ as measured using the oven dry method of moisture content measurement. In evaluating the machine's performance, the standard code proffered for seed drills by Mehta et al., (1995) was used.

\section{Calibration}

The procedure of testing the manually operated seed-cum fertilizer soybean planter, the hopper of the planter was fully loaded with $5 \mathrm{~kg}$ seed and $5 \mathrm{~kg}$ fertilizer of soybean seeds. The planter was jacked up to allow for free rotation of the drive or transport wheel. A mark was made on the wheels to indicate the reference point to count the number of revolutions when turned, and a polythen bag was placed on the discharge tube to collect the seeds discharged. The drive wheels were rotated 100 times at low speed. A stop clock was used to measure the time taken to complete the revolutions. The seed in the polythen bag were weighed on a balance and the procedure was repeated 10 times. Similar test was carried out for each crop seed (Olajide and Manuwa, 2014).

\section{Seed germination test}

Laboratory germination tests were normally conducted at different temperature for different seeds. Count out 100 seeds (including damaged ones) and sow in 15 rows of 15 seeds, the rows make it easier to count seedlings. Seeds should be sown at normal seeding depth of 2-4 cm in seed germinator.

Place the seeds on top of the sand or soil and push them in with a piece of dowel or a pencil and cover with a little more sand. Counting Seedlings after 15 days when the majority of seedlings were up. Do not wait until the late ones emerge-these are the damaged, weak ones. Only normal seedlings were counted.

\section{Seed damage percentage}

The hoppers were loaded with $5 \mathrm{~kg}$ of seeds and drive wheels were rotated 20 times with speed of corresponding to $0.9 \mathrm{~m} / \mathrm{s}$. A stop watch was used to measure the time taken to complete the revolutions. Polythene bags were placed on each of the tubes/ spouts collected the seeds metered and discharged. The seeds collected in the polyethylene bags

At the end of the 20 revolution of the wheel were examined for any external damage or visible crack to establish the performance of the metering wheel. Germination tests, on randomly picked seed samples, were conducted at the laboratory to assess the level of internal damage by the metering mechanism. Percentage external seed damage was determined by equation given below.

$M_{d}=\frac{S_{\text {t } d x}}{S_{n s}} \times 100$

Where: 
$\mathrm{Md}=$ percentage damaged seed

Stds $=$ total number of damaged seeds (external)

Sns $=$ total number of seeds

\section{Uniformity of seed spacing}

To determine the uniformity of seed spacing (Seed to seed spacing in row) of manually operated seed-cum fertilizer soybean planter, the planter was fully loaded with seed. A 10 $\mathrm{m}$ thin layer of grease layer was laid out on the plain ground and the machine was run at walking speed of approximately $2.75 \mathrm{~km} / \mathrm{hr}$. A measuring steel tape was used to measure the distance between seed to seed in the row. This process was repeated five times and measurement of distance between seed to seed was recorded. Similar test was carried out for each crop seed. (Oduma et al., 2014)

\section{Missing index}

It was estimated using distance measured between seeds dropped in the row and spaced at a distances greater than 1.6 times the theoretical. Accurate missing rate of seed measurement during operation in the field was not easy task, keen attention is needed while operating the manually operated planter in the field (laboratory testing grease layer).

So, during operation operator and one observer counted the number of seeds missed to drop into the seed tube. Then determined the actual number of seeds drop in experimental area if no missing occurred. Then missing rate is determined by the following equation (Oduma et al., 2014).

Percent missing rate $=\frac{N}{M} \times 100$

$\mathrm{N}=$ number of seeds missing during pickup by metering wheel into seed tube
$M=$ number of seed dropped by the metering wheel if no missing occurred and not more than one seed per cell

\section{Multiples index}

It was estimated by measuring the distance between consecutive seeds, the spacing less than or equal to half of the theoretical spacing and calculated as follows:

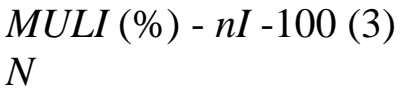

Where:

MULI $=$ multiple index

$\mathrm{nI}=$ the number of spacing's in region I and

$\mathrm{N}=$ total number of spacing's.

\section{Theoretical field capacity}

Theoretical and effective field capacity of the soybean seeder was determined by the following equation (Hossain, 2014)

$\mathrm{TFC}=\frac{\frac{5 W}{10}}{10}(4)$

Where,

TFC $=$ theoretical field capacity, ha/hr

$\mathrm{S}=$ forward speed, $\mathrm{km} / \mathrm{hr}$

$\mathrm{W}=$ width of coverage, $\mathrm{m}$

\section{Field test}

A field of $12 \mathrm{~m} \mathrm{X} 15 \mathrm{~m}$ was used for the performance test of the seed-cum fertilizer soybean planter. This field was properly tilled plough and harrowed to obtain a good soil condition for the crop and workable condition for the planter. The field efficiency, field capacity, planting depth of seed and uniformity of seed spacing were detained. The actual performance at a speed of $2.25-2.80$ $\mathrm{km} / \mathrm{h}$. Field capacity and efficiency were 
determined in accordance to the recommendation made by Kepner (1978) and using relevant parameters that included effective operation time, turning time and time losses due to obstructions on the field.

\section{Operating speed}

The speed of the planter is important role for better performance during operation. If the speed is more than to recommended speed, its more damage seeds and affect seed to seed distance in the row but in other way if speed is less, efficiency of planter automatically reduce. So for better performance normal walking was good. The actual speed in the field was measured by two mark made in the field at a distance of $15 \mathrm{~m}$. One person stood a first mark with a stop watch when the planter was started for the operation the stop watch was switched on and the time was noted to cover $15 \mathrm{~m}$ distance. Five observations were taken and speed was calculated on the basis average time taken to 15 meter distance. The speed was varying $2.0,2.5-3.0 \mathrm{~km} / \mathrm{hr}$. The average speed was $2.5 \mathrm{~km} / \mathrm{hr}$ at the time of planting operation

\section{Measurement of wheel slippage percentage}

A $15 \mathrm{~m}$ long test run was taken for the measurement of wheel slip. The manually operated seed-cum-fertilizer soybean planter was first operated with seed cum-fertilizer planter with the load and total revolution was counted to move on the same length without load and wheel revolution was counted. The wheel slip was calculated as per the following equation.

Wheel Slippage $(\%)=\frac{\frac{W 1-N 2}{N 1} \times 100}{N_{1}}$

Where:

$\mathrm{N}_{1}=$ Total number of revolution of wheel at without load
$\mathrm{N}_{2}=$ Total number of revolution of wheel at load

\section{Missing hills}

Observations for missing hills were taken after twenty days of planting operation. The total number of missing hill was counted separately for one row in a $15 \mathrm{~m}$ distance. These observations were repeated five times for each crop seed. Similar test was carried out for each crop seed. The total percentage of missing hills was calculated by following method (Hossain, 2014)

Missing hill $\%=$

Actwal number of missing intll in $12 \mathrm{~m}$

Theoretical number of intll to be planted in $12 \mathrm{~m}$

\section{Field efficiency}

Field efficiency represents the ratio of effective field capacity to theoretical field capacity and was expressed as percentage. The field capacity was calculated by following formula (J. Sahay, 2004). It was calculated as follows from the field test data.

$E_{f}=\frac{E F C}{C_{T}} X 100$

Where,

$\mathrm{E}_{\mathrm{f}}=$ Field efficiency, $\%$

$\mathrm{C}_{\mathrm{T}}=$ Theoretical field capacity, ha/h

$C_{\mathrm{T}}=\frac{\text { SXW }}{10}$

$\mathrm{S}=$ Average speed of travel, $\mathrm{km} / \mathrm{h}$

$\mathrm{W}=$ Average working width of equipment, $\mathrm{m}$ $\mathrm{EPC}=$ Effective field capacity, ha/h

\section{Results and Discussion}

The performance of a seed-cum fertilizer soybean planter capable of planting soybean seeds at predetermined spacing's and depths. Physical properties of seeds involved in the study were investigated to optimize the design 
of the planter's component parts. The experimental finding of the present investigation to development and testing of a seed-cum fertilizer soybean planter and their interpretation are presented in this chapter under the following subheads

Table.1 Specifications of manually operated seed-cum fertilizer soybean planter

\begin{tabular}{|c|c|c|}
\hline Sr. No & Parameter & Specifications \\
\hline 1. & Length & $160 \mathrm{~cm}$ \\
\hline 2. & Height & $110 \mathrm{~cm}$ \\
\hline 3. & Width & $22 \mathrm{~cm}$ \\
\hline 4. & Furrow opener & Shoe type \\
\hline 5. & $\begin{array}{l}\text { Seed and fertilizer } \\
\text { metering device }\end{array}$ & Wheel type, 18 cells, $104 \mathrm{~cm}$ dia. \\
\hline 6. & Ground wheel & $47.5 \mathrm{~cm}$ diameter \\
\hline 7. & Nut and bolts & 20 number \\
\hline 8. & $\begin{array}{l}\text { Seed and Fertilizer } \\
\text { hopper }\end{array}$ & $\begin{array}{c}25.5 \mathrm{~cm} \text { height, } 15.5 \mathrm{~cm} \text { bottom width, } 25.5 \mathrm{~cm} \\
\text { top width and } 20 \mathrm{~cm} \text { height between hopper } \\
\text { edges }\end{array}$ \\
\hline 9. & $\begin{array}{l}\text { Seed and Fertilizer } \\
\text { tube }\end{array}$ & $2.7 \mathrm{~cm}$ Outside diameter and length adjustable \\
\hline 10. & Power transmission & $\begin{array}{l}\text { Ground wheel, Chain, Small sprocket, large } \\
\text { sprocket, }\end{array}$ \\
\hline 11. & Weight & $25 \mathrm{~kg}$ \\
\hline
\end{tabular}

Table.2 Germination test for soybean seed pre metered with different samples

\begin{tabular}{|c|c|c|c|c|c|c|c|}
\hline \multirow[t]{2}{*}{ Variables } & \multirow{2}{*}{$\begin{array}{l}\text { Number of } \\
\text { pre metered } \\
\text { seeds taken } \\
\text { for } \\
\text { germination }\end{array}$} & \multicolumn{5}{|c|}{ Number of germinated seeds } & \multirow{2}{*}{ Average } \\
\hline & & R1 & $\mathbf{R 2}$ & $\mathbf{R 3}$ & R4 & $\mathbf{R 5}$ & \\
\hline G1P1 & 100 & 89 & 91 & 88 & 92 & 93 & 90.6 \\
\hline G1P2 & 100 & 82 & 85 & 80 & 88 & 86 & 84.2 \\
\hline G1P3 & 100 & 92 & 95 & 89 & 94 & 96 & 93.2 \\
\hline G2P1 & 100 & 88 & 89 & 91 & 90 & 86 & 88.8 \\
\hline G2P2 & 100 & 81 & 82 & 86 & 82 & 88 & 83.8 \\
\hline G2P3 & 100 & 80 & 88 & 86 & 82 & 85 & 84.2 \\
\hline G3P1 & 100 & 89 & 94 & 96 & 92 & 95 & 93.2 \\
\hline G3P2 & 100 & 91 & 90 & 86 & 88 & 89 & 88.8 \\
\hline G3P3 & 100 & 80 & 88 & 86 & 82 & 85 & 84.2 \\
\hline
\end{tabular}

Note- G1: Full hopper; G2: Half hopper; G3: Quarter hopper; P1: Planter speed (2.0 km/h); P2: planter speed (2.5 $\mathrm{km} / \mathrm{h}) ;$ P3: Planter speed $(3.0 \mathrm{~km} / \mathrm{h})$ 
Table.3 Mechanically Damaged Seed of due to manually operated seed-cum fertilizer soybean planter for different samples

\begin{tabular}{|c|c|c|c|c|c|c|c|c|c|c|c|c|}
\hline \multirow[t]{2}{*}{ Soil. } & \multirow{2}{*}{$\begin{array}{l}\text { Total } \\
\text { number of } \\
\text { seeds taken } \\
\text { from planter }\end{array}$} & \multicolumn{5}{|c|}{ Number of non-damaged seeds } & \multicolumn{5}{|c|}{ Number of damaged seeds } & \multirow{2}{*}{$\begin{array}{l}\text { Average } \\
\text { percentage } \\
\text { of damaged } \\
\text { seeds }\end{array}$} \\
\hline & & R1 & $\mathbf{R 2}$ & $\mathbf{R 3}$ & $\mathbf{R 4}$ & R5 & $\mathbf{R 1}$ & $\mathbf{R 2}$ & $\mathbf{R 3}$ & $\mathbf{R 4}$ & R5 & \\
\hline G1P1 & 100 & 98 & 96 & 97 & 98 & 97 & 2 & 4 & 3 & 2 & 3 & 2.8 \\
\hline G1P2 & 100 & 94 & 95 & 94 & 96 & 94 & 6 & 5 & 6 & 4 & 6 & 5.4 \\
\hline G1P3 & 100 & 93 & 94 & 94 & 95 & 93 & 7 & 6 & 6 & 5 & 7 & 6.2 \\
\hline G2P1 & 100 & 98 & 99 & 94 & 95 & 96 & 2 & 1 & 6 & 5 & 4 & 3.6 \\
\hline G2P2 & 100 & 97 & 96 & 96 & 98 & 97 & 3 & 4 & 4 & 2 & 3 & 3.2 \\
\hline G2P3 & 100 & 95 & 96 & 94 & 94 & 95 & 5 & 6 & 6 & 6 & 5 & 5.6 \\
\hline G3P1 & 100 & 99 & 98 & 100 & 98 & 99 & 1 & 2 & 0 & 2 & 1 & 1.2 \\
\hline G3P2 & 100 & 98 & 97 & 95 & 97 & 99 & 2 & 3 & 5 & 3 & 1 & 2.8 \\
\hline G3P3 & 100 & 96 & 98 & 94 & 97 & 96 & 4 & 2 & 6 & 3 & 4 & 3.8 \\
\hline
\end{tabular}

Note- G1: Full hopper; G2: Half hopper; G3: Quarter hopper; P1: Planter speed (2.0 km/h); P2: planter speed (2.5 $\mathrm{km} / \mathrm{h}) ;$ P3: Planter speed $(3.0 \mathrm{~km} / \mathrm{h})$

Table.4 Test of distance of dropped fertilizer on grease layer by manually operated seed-cum fertilizer planter for different speed and different hopper level

\begin{tabular}{|c|c|c|c|c|c|c|c|c|}
\hline \multirow[t]{2}{*}{ Obs. No. } & \multirow{2}{*}{$\begin{array}{l}\text { Length } \\
\text { of the } \\
\text { field (m) }\end{array}$} & \multirow{2}{*}{$\begin{array}{c}\text { Standard } \\
\text { distance to } \\
\text { seed drop } \\
(\mathrm{cm})\end{array}$} & \multicolumn{5}{|c|}{ Actual distance of dropped seed $(\mathbf{c m})$} & \multirow{2}{*}{$\begin{array}{c}\text { Average } \\
\text { distance of } \\
\text { dropped } \\
\text { seed (cm) }\end{array}$} \\
\hline & & & $\mathbf{R 1}$ & $\mathbf{R 2}$ & $\mathbf{R 3}$ & $\mathbf{R 4}$ & $\mathbf{R 5}$ & \\
\hline G1P1 & 10 & 35 & 34.30 & 33.25 & 33.58 & 34.05 & 33.62 & 33.76 \\
\hline G1P2 & 10 & 35 & 33.54 & 33.12 & 34.30 & 32.52 & 36.70 & 34.03 \\
\hline G1P3 & 10 & 35 & 36.50 & 35.15 & 35.16 & 37.40 & 34.80 & 35.80 \\
\hline G2P1 & 10 & 35 & 33.12 & 34.64 & 33.22 & 32.02 & 31.52 & 32.90 \\
\hline G2P2 & 10 & 35 & 31.52 & 36.16 & 32.14 & 31.52 & 32.02 & 32.67 \\
\hline G2P3 & 10 & 35 & 33.22 & 36.72 & 34.25 & 31.52 & 31.52 & 33.44 \\
\hline G3P1 & 10 & 35 & 35.14 & 34.83 & 33.95 & 34.64 & 33.52 & 34.41 \\
\hline G3P2 & 10 & 35 & 34.05 & 34.02 & 31.52 & 36.16 & 32.14 & 33.57 \\
\hline G3P3 & 10 & 35 & 33.54 & 33.12 & 34.64 & 32.02 & 31.52 & 32.96 \\
\hline
\end{tabular}

Note- G1: Full hopper; G2: Half hopper; G3: Quarter hopper; P1: Planter speed (2.0 km/h); P2: planter speed (2.5 $\mathrm{km} / \mathrm{h})$; P3: Planter speed $(3.0 \mathrm{~km} / \mathrm{h})$

Table.5 Determination of drawbar power in sandy loam soil

\begin{tabular}{|c|c|c|c|c|c|}
\hline Obs. No. & $\begin{array}{c}\text { Pushing angle, } \\
\text { (degree) }\end{array}$ & $\begin{array}{c}\text { Pushing } \\
\text { Force (kg) }\end{array}$ & Draft force (N) & $\begin{array}{c}\text { Drawbar power } \\
\text { (hp) }\end{array}$ & Dbp in (watts) \\
\hline S1G1P1 & 45 & 14 & 105.25 & 0.096 & 74.12 \\
\hline S1G1P2 & 45 & 15.6 & 109.80 & 0.11 & 75.69 \\
\hline S1G1P3 & 45 & 16.8 & 113.35 & 0.13 & 76.90 \\
\hline S1G2P1 & 45 & 13.8 & 103.4 & 0.086 & 73.12 \\
\hline S1G2P2 & 45 & 14.6 & 106.2 & 0.10 & 74.12 \\
\hline S1G2P3 & 45 & 15.4 & 108.7 & 0.11 & 75.59 \\
\hline S1G3P1 & 45 & 13 & 102.6 & 0.078 & 73.12 \\
\hline S1G3P2 & 45 & 13.6 & 103.1 & 0.098 & 74.20 \\
\hline S1G3P3 & 45 & 14.2 & 105.90 & 0.10 & \\
\hline
\end{tabular}


Table.6 Slippage of ground drive wheel of manually operated seed-cum fertilizer soybean planter for clay loam soil

\begin{tabular}{|c|c|c|c|c|c|}
\hline Obs. No. & $\begin{array}{c}\text { Distance } \\
\text { travelled }(\mathbf{m})\end{array}$ & $\begin{array}{c}\text { Theoretical } \\
\text { revolution of } \\
\text { drive wheel }\end{array}$ & $\begin{array}{c}\text { Actual } \\
\text { revolution of } \\
\text { drive wheel }\end{array}$ & $\begin{array}{c}\text { Slippage } \\
(\mathbf{m})\end{array}$ & $\begin{array}{c}\text { Slippage } \\
\mathbf{( \% )}\end{array}$ \\
\hline S1G1P1 & 15 & 45.87 & 44.20 & 1.67 & 3.64 \\
\hline S1G1P2 & 15 & 45.87 & 43.15 & 2.72 & 5.93 \\
\hline S1G1P3 & 15 & 45.87 & 42.90 & 2.97 & 6.47 \\
\hline S1G2P1 & 15 & 45.87 & 43.12 & 2.75 & 5.99 \\
\hline S1G2P2 & 15 & 45.87 & 42.80 & 3.07 & 6.69 \\
\hline S1G2P3 & 15 & 45.87 & 41.85 & 4.02 & 8.76 \\
\hline S1G3P1 & 15 & 45.87 & 42.12 & 3.75 & 8.17 \\
\hline S1G3P2 & 15 & 45.87 & 41.45 & 4.42 & 9.63 \\
\hline S1G3P3 & 15 & 45.87 & 40.24 & 5.63 & 12.27 \\
\hline
\end{tabular}

Note- G1: Full hopper; G2: Half hopper; G3: Quarter hopper; P1: Planter speed (2.0 km/h); P2: planter speed (2.5 $\mathrm{km} / \mathrm{h}) ;$ P3: Planter speed $(3.0 \mathrm{~km} / \mathrm{h})$

Size of soybean seeds

\begin{tabular}{|l|c|}
\hline Particular (mm) & Size of Soybean seed (Mini. to Max.) \\
\hline Length & $8 \pm 9.5$ \\
\hline Width & $6.6 \pm 7.5$ \\
\hline Thickness & $5.6 \pm 6$ \\
\hline Geometric Diameter & $6.73 \pm 7.88$ \\
\hline
\end{tabular}

Fig.1 Top and front view of the seed-cum fertilizer soybean planter

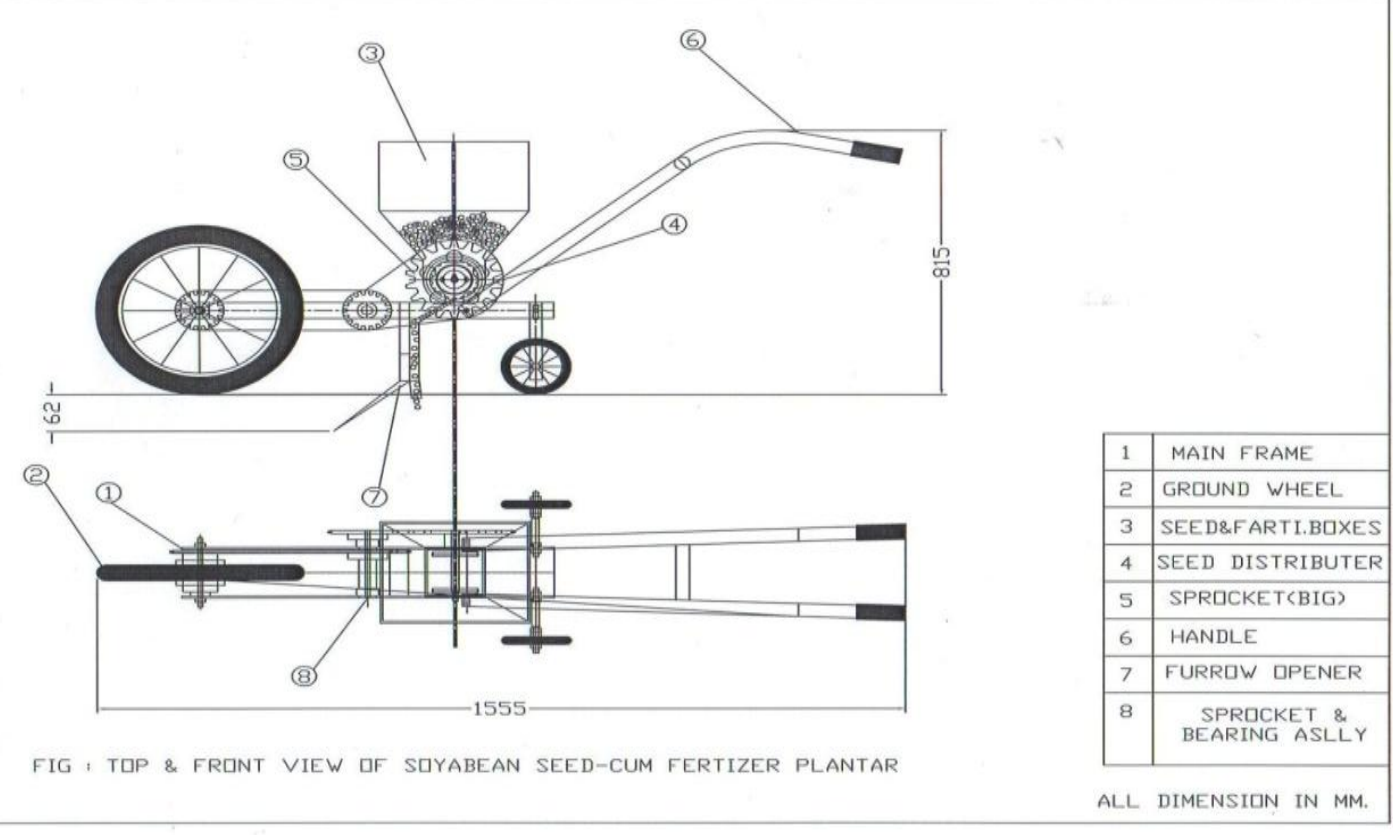


Fig.2 Top and front view of hopper seed-cum fertilizer planter

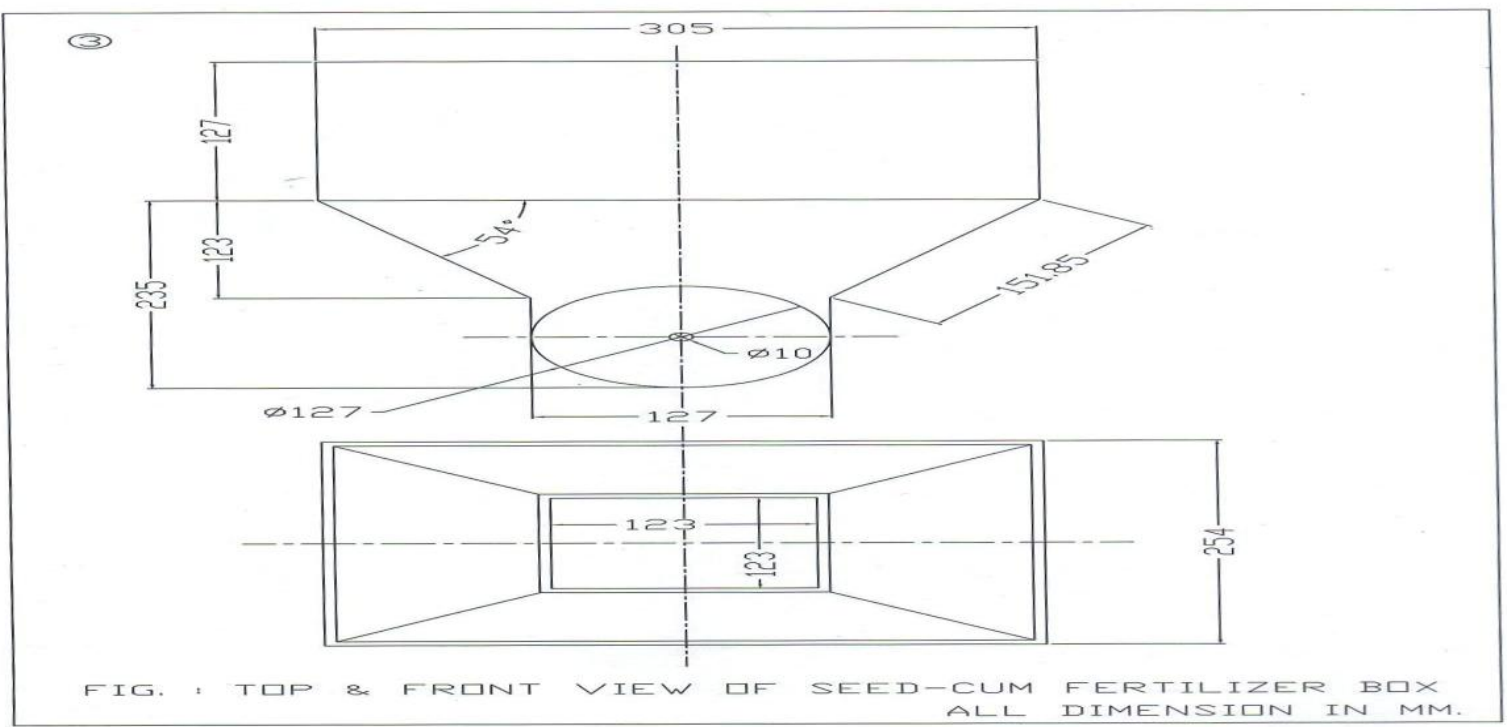

A good progress of the work has been made successfully. Therefore, the low cost manually operated soybean planter may be accepted for demonstration and use. The average length, width, thickness and geometric mean diameter of the soybean seed were $6.95 \mathrm{~mm}, 6.02 \mathrm{~mm}, 4.52 \mathrm{~mm}$ and 6.20 $\mathrm{mm}$ respectively. The maximum length of the seed was $7.42 \mathrm{~mm}$ and minimum was 5.99 $\mathrm{mm}$, maximum width of the seed was 6.45 $\mathrm{mm}$ and minimum was $5.01 \mathrm{~mm}$, maximum thickness of the seed was $4.60 \mathrm{~mm}$ and minimum was $4.01 \mathrm{~mm}$, maximum geometric mean diameter of seed was $6.55 \mathrm{~mm}$ and minimum was $5.50 \mathrm{~mm}$. The shape was determined on the basis of sphericity of the seed. The data obtained has been presented in appendix table 1 . Sphericity of the soybean ranges from 0.85 to 0.98 the maximum bulk density and true density of the soybean seed were $0.87 \mathrm{~g} / \mathrm{cm}^{3}$ and $1.36 \mathrm{~g} / \mathrm{cm}^{3}$ respectively. And the minimum bulk density and true density of the soybean seed were $0.82 \mathrm{~g} / \mathrm{cm}^{3}$ and $1.33 \mathrm{~g} / \mathrm{cm}^{3}$ respectively. The angle of repose and coefficient of static friction were measured as maturity. The average value for angle of repose of soybean seed was 30.61 degree. The average coefficient of static friction of soybean seed was 0.48 respectively. The weight of 1000 seeds of soybean was $98.40 \mathrm{~g}$ and respectively. The maximum weight of 1000 seeds of soybean was $104 \mathrm{~g}$ respectively. The minimum weight of 1000 seeds of soybean 94.5 respectively. The germination test of pre metered seeds of soybean revealed that the percentage of the germination of the soybean seeds was 87.88 $\%$ while the minimum germination percentage in one sample was found $83.80 \%$ and maximum germination percentage in one sample was found $93.2 \%$. The number of cells on periphery of seed metering wheel was found to be 18 for soybean crop. The number of cells on periphery of fertilizer metering wheel was found to be 18 for fertilizer.

Calibration of the manually operated seedcum fertilizer soya bean planter has been done in the laboratory; its observations there were $3 \%$ for full hopper, $3.33 \%$ for half hopper and $3.75 \%$ for quarter hopper seed missing during test. The average amount of seed in fifty revolutions of drive wheel was calculated 47.23 for five replications and drive 0.004410 ha. After the calibration it found that the amount of the seeds required. 


\section{References}

Adisa A F, Braide F. G, "Design And Development of Template Row Planter", Transnational Journal of Science and Technology August 2012 edition vol. 2, No.7

Abubakar, "The Principle of Jab Planter in Applying Fertilizers", 1987

Adekoya, Buchel"Developed A Cam Activated Precision Punch Planter",Transnational Journal of Science1987.

Anisha, Geeta and Mishra, B.P. (2014). Testing of the pneumatic planter with okra seed under laboratory conditions. International Journal of Plant Sciences. Vol. 9(1), 61-66.

Anonymous, (2013). Phal Phul Sabji Uttapadan Avam Parirakshan (Package Practice). Directorate of Extension Education, Chaudhary Charan Singh Haryana Agricultural University, Hisar. 166-167.

Anonymous, (2014a). Key Indicators of Land and Livestock Holding in India. National Sample Survey Office (NSSO), Ministry of Statistics and Programme Implementation, Government of India. Retrieved from website 'http://mospi.nic.in/Mospi_New/uploa d/KI_70_18.1_19dec14.pdf' on 5 June, 2016.

Anonymous, (2014b). Indian Labour Statistics 2012 and 2013. Labour Bureau, Ministry of Labour and Employment, Government of India.

Bamiro, O.A, Nurudeen, A. and Akuru, I.O. 1986. Introductory Technology for schools and colleges. Evans Brothers (Nigeria publishers) limited. PP 227233.

Chakraverty, A. (1981). Handbook of Postharvest Technology: Cereals, Fruits, Vegetables, Tea, and Spices.
CRC Press, Boca Raton, United States of America.

CosKuner, Y. and Karababa, E. (2007). Physical properties of coriander seeds (Coriandrum sativum L.). Journal of Food Engineering. Vol. 80(2), 408416.

Chauhan, B.S., Mahajan, G., Sardana, V., Timsina, J. and Jat, M.L. (2012). Productivity and Sustainability of the Rice Wheat Cropping System in the Indo- Gangetic Plains of the Indian subcontinent: Problems, Opportunities, and Strategies. Advances in Agronomy, Volume 117, DOI: http://dx.doi.org/10.1016/B9780-12- 394278-4.00007-6.

Kumar.D et al.,l., (2017) Development And Performance Evaluation Of A Manually Operated Seed-Cum Fertilizer Soybean Planter. P.

Gardner, F.P., R.B. Pearch, and R.L. Mitchell. (1985). Seed and Germination. P. 213 In Gardner et al., (ed.) Physiology of Crop Plants. Iowa State University Press, Ames, IA.

Hamman, B., B.D. Egli, and G. Koning. (2002). Seed vigor, soilborne pathogens, preemergent growth and soybean seedling emergence. Crop Sci. 42:451-457.

Hatfield, J.L. and D.B. Egli. (1974). Effect of temperature on the rate of soybean hypocotyl elongation and field emergence. Crop Sci. 14:4423-426.

Heatherly, L.G. (1988). Planting date, row spacing, and irrigation effects on soybean grown on clay soil. Agron. J. 80:227-231.

Helms, T.C., E. Deckard, R.J. Goos, and J.W. Enz. (1996). Soybean seedling emergence influenced by days of soil water stress and soil temperature. Agron. J. 88:657-661.

Hicks, D.R. (1978). Growth and Development. p. 19 In A. G. Norman 
(ed.) Soybean Physiology, Agronomy, and Utilization. Academic Press, New York.

Holshouser, D.L. and J.P. Whittaker. (2002). Plant population and row-spacing effects on early soybean production systems in the Mid-Atlantic USA. Agron. J. 94:603- 611.

Hunter, J.R. and A.E. Erickson. (1952). Relation of seed germination to soil moisture tension. Agron. J. 44:107109.

Hsu, K.L., K.T. Pilobello and L.K. Mahal, (2006).Analysing the dynamic bacterial glycome with a lectin microarray approach. Nat.Chem. Biol., 2: 153-157.

Julieta Pérez-Giménez, Elías J. Mongiardini, M. Julia Althabegoiti, Julieta Covelli, J. Ignacio Quelas, Silvina L. LópezGarcía, and Aníbal R. Lodeiro, (2009). Soybean Lectin Enhances Biofilm Formation by Bradyrhizobium japonicum in the Absence of Plants, International Journal of Microbiology Volume 2009 Article ID 719367.

IS 2720-2 (1973): Methods of test for soils, Part 2: Determination of water content [CED 43: Soil and Foundation Engineering]. Bureau of Indian Standards (BIS).

Jayan, P.R. and Kumar, V. J. F. (2004). Planter design in relation to the physical properties of seeds. Journal of Tropical Agriculture. 42 (1-2), 69-71.

Khan, K., Moses, S. C. and Kumar, A. (2015). The Design and Fabrication of a Manually Operated Single Row MultiCrops Planter. IOSR Journal of Agriculture and Veterinary Science. Vol. 8, 147-158.

Majumder, J. (2014). Anthropometric dimensions among Indian males-A principal component analysis. Eurasian Journal of Anthropology. Vol. 5(2), 54-62.
Maheshwarr, T. K. and Verma, M.R. (2007). Modification and Performance Evaluation of Garlic Planter, Agricultural Engineering Today. Vol. 31(2), 11-14.

Mehta, C. R., Chandel, N. S., Senthilkumar, T. and Singh, K. K. (2014). Trends of Agricultural Mechanization in India. Trends of Agricultural Mechanization in India, CSAM Policy Brief. 2-3.

Mohsenin, N.N. (1986). Physical Properties of Plant and Animal Materials (2nd Edition.). Gordon and Breach Science Publications, New York..

Oluka, S.I and Nwuba, E.I.U (2001). "Physical and Aerodynamic properties of cowpea seeds, Hulls and Stalks". JEAS vol1, No1, Sept. 2001. Pp.3543,

Steele, N.M. (1972). Cowpea in Nigeria. Unpublished Ph.D. Thesis. University of Reading, Reading, U.K.

Saharawat, Y.S., Singh, B., Malik, R.K., Ladha, J.K., Gathala, M., Jat, M.L. and Kumar, V. (2010). Evaluation of alternative tillage and crop establishment methods in a ricewheat rotation in north-western IGP. Field Crops Res. 116: 260-267.

J.E. Iken and N.A. Amusa, Maize research and production in Nigeria. (2004) African Journal of Biotechnology, Vol. 3 (6), pp. 302-307.

Maize, http://old.iita.org/cms/details/maize _project_details.aspx?zoneid=63\&arti cleid=273, 18/4/2014.

C.G. Carlson, T.A. Doerge and D.E.(2004) Clay, Estimating Corn Yield Losses from Unevenly Spaced Planting. SSMG, $\quad$ pp. 1-4. http://nue.okstate.edu/CORN/Corn_Yi eldLoss.pdf,

Vasilas, B.L., G.E. Pepper, and M.A. Jacob. (1990). Stand reductions, replanting, and offset row effects on soybean yield. J. Prod. Agric. 3:120-123. 
Walker, J.T. 1983. Irregular stand effects on yields of soybean. M.S. thesis. Univ. of Illinois, Urbana.

Weaver, D.B., R.L. Akridge, and C.A. Thomas. (1991). Growth habit, planting date, and row-spacing effects on late-planted soybean. Crop Sci. 31:805-810.

Woodstock, L.W. and R.B. Taylorson. (1981). Ethanol and acetaldehyde in imbibing soybean seed in relation to deterioration. Plant Physiol. 67:424428.

Wrather, J.A., T.R. Anderson, D M. Arsyad, Y. Tan, L D. Ploper, A. Porta-Puglia, H. H. Ram, and J.T. Yorinori. (2001). Soybean disease loss estimates for the top ten soybean-producing countries in 1998. Can. J. Plant Pathol. 23:115121.

Wuebker, E.F., R E. Mullen, and K. Koehler. (2001). Flooding and temperature effects on soybean germination. Crop Sci. 41:1857-1861.

Zhang, B.Q. and X.B. Yang. (2000). Pathogenicity of Pythium populations from corn- soybean rotation fields. Plant Dis. 84:94-99.

Wakchaure, D., Thakur, S. S., Singh M. and Sharma A. (2013). Pneumatic metering mechanism for sowing of carrot seeds. J Res Punjab agric Univ. 50 (3 \& 4), 144-146.

Yadachi, S., Mani, I., Kalra, M. S., Kumar, A. and Sahoo, P. K. (2005). Development and evaluation of inclined plate metering mechanism for carrot seed. Journal of Agricultural Engineering. Vol. 50(2).

Yenpayub, J., Kingthong, S. and Benjaphragairat J. (2014). Design and Development of a Garlic Planter in Thailand. King Mongkut's Institute of Technology, Lardkabang

\section{How to cite this article:}

Devesh Kumar and Ashok Tripathi. 2017. Development and Performance Evaluation of a Manually Operated Seed-Cum Fertilizer Soybean Planter. Int.J.Curr.Microbiol.App.Sci. 6(11): 2984-2996. doi: https://doi.org/10.20546/ijcmas.2017.611.349 